\title{
Cellulolytic and lipolytic fungi isolated from soil and leaf litter samples from the Cerrado (Brazilian Savanna)
}

\author{
Mayara de Melo, Ana Carolina V. Araujo, Marianne A. N. Chogi \& Iolanda C. S. Duarte* \\ Department of Biology, Federal University of São Carlos, São Paulo, Brazil; mayarademeloo@gmail.com, \\ acvaraujo@gmail.com, marianneakemi@hotmail.com, iolanda.duarte@gmail.com \\ * Correspondence
}

Received 05-VI-2017. Corrected 19-X-2017. Accepted 18-XI-2017.

\begin{abstract}
The Brazilian savanna, known as the Cerrado, is a biome with a high degree of endemism, with the potential to house many microorganisms suitable for biotechnological exploitation, especially fungi. The Cerrado soil, which is usually acidic, is a favorable environment for the growth of fungi capable of degrading lignocellulosic materials. The aim of the present study was to isolate cellulolytic filamentous fungi native to the Cerrado. Samples of soil and leaf litter were collected in three points of Cerrado State Park, located in the South of Brazil, during the rainy season in September 2014. Samples were stored in sterile plastic bags, transported at room temperature and kept at $4{ }^{\circ} \mathrm{C}$ for three days. Filamentous fungi were isolated by successive inoculations in PDA (maintained at $30^{\circ} \mathrm{C}$ ). Cellulase activity was tested in CMC (carboxymethyl cellulose) medium and lipase activity was assessed in medium containing phenol red and tween 20 (incubated at $37^{\circ} \mathrm{C}$ ), and in medium supplemented with Rhodamine B (kept at $30^{\circ} \mathrm{C}$ ). We isolated a total of 28 strains, 25 produced cellulase, detected with lugol in strains grown in CMC medium. The isolates were identified morphologically (color, form of growth) and by sequencing of the $18 \mathrm{~S}$ rRNA region, with both techniques producing congruent results. One strain of Colletotrichum boninense and one strain of Trichoderma sp., both isolated from soil samples, presented the highest cellulolytic activity. All strains exhibited lipolytic activity, with enzyme production and activity influenced by temperature. The present study revealed new strains of known filamentous fungi that can be applied in biomass degradation. These strains are suitable for optimization of culture conditions, which could lead to the economic feasibility of the process. Rev. Biol. Trop. 66(1): 237-245. Epub 2018 March 01.
\end{abstract}

Key words: cellulose; lipase; filamentous fungi; lignocellulosic materials; Brazilian savanna.

Cellulose, the main constituent of plant cell walls, is the world's most abundant polysaccharide and with an annual production estimated at $1.5 \times 10^{12}$ tons of biomass (Klemm, Heublein, Fink, \& Bohn, 2005). Dry biomass on Earth, mainly cellulose, is estimated to $1.85-2.4 \times 10^{12}$ tons (Hodásová, Jablonský, Škulcová, \& Ház, 2015). This represents an almost inexhaustible source of polysaccharides, which may be harnessed for industrial and biotechnological purposes. Brazil is the largest producer of ethanol from sugar cane, a process that generates lignocellulosic residues of around $250 \mathrm{~kg}$ of bagasse for each liter of ethanol (Balat, 2011). While this residue can be converted to biofuel, the resistance of lignocellulosic materials hampers its direct bioconversion in fermentative processes (Sticklen, 2008).

Degradation of lignocellulose into sugars is the first step required for its use and can be achieved chemically, enzymatically or by a combination of both processes (Balat, 2011). Cellulase (EC 3.2.1.4), laccase (EC 1.11.1.7) and lipase (EC 3.1.1.3) are three enzymes involved in the degradation of lignocellulose. Lipase acts as a catalyst of this process, breaking down acids and resin formed during lignocellulose degradation (Karlsson, Holmbom, Spetz, Mustranta, \& Buchert, 2001). 
Fungi are important producers of enzymes for industry, with cellulase accounting for nearly $20 \%$ of the total world enzyme market (Lange et al., 2012). They are key players in litter decomposition, due to the fact they produce a wide range of extracellular enzymes and are resistant to environmental stress (Valencia \& Chambergo, 2013). They are therefore of interest for biotechnological applications in food, wine and textiles industries (Bhat, 2000; Viswanath, Rajesh, Janardhan, Kumar, \& Narasimha, 2014), for energy generation (Balat, 2011), for plastics degradation (Kathiresan, 2003) and to produce high-added value compounds such as biosensors, cosmetic products and organic acids (Hasan, Shah, \& Hameed, 2006; Oliveira \& Graaff, 2011). Bioprospecting microorganisms that can produce enzymes with higher specific activity and efficiency are mandatory in biotechnological processes.

It is estimated that there are approximately 5.1 million fungi species in the world, of which only $2 \%$ are known (Blackwell, 2011; Maia et al., 2015). While the Brazilian savanna is a biodiversity hotspot, it is subject to a high rate of deforestation (Trancoso, Sano, \& Meneses, 2015) which decreases fungal diversity in its soil (Castro et al., 2008). The soil of the region is red or yellow latosol, has a low $\mathrm{pH}$, low cation exchange capacity, high aluminum saturation and a high clay content (Oliveira-Filho \& Ratter, 2002; Castro et al., 2008; Castro, Silva, Quirino, Bustamante, \& Krüger, 2016). There is a great number of non-identified microorganisms in this environment (Castro et al., 2008; Vieira, Johann, Hughes, Rosa, \& Rosa, 2014; Maia et al., 2015; Castro et al., 2016) and, since high aluminum saturation is generated due to laccase enzymatic activity (Viswanath et al., 2014), this feature indicates Cerrado soil might harbor lignocellulolytic fungi. Leaf litter is also an important source of cellulolytic fungi, as they produce extracellular enzymes to degrade wood and leaves (Korkama-Rajala, Mueller, \& Pennanen, 2008).

The aim of the present study, therefore, was to isolate, identify and detect cellulase and lipase activity in fungi collected from the
Cerrado State Park in Brazil, and in this way, to provide further information on the biotechnological resources of the Brazilian savanna.

\section{MATERIAL AND METHODS}

Area: The soil and leaf litter samples were collected in the Cerrado State Park, located in

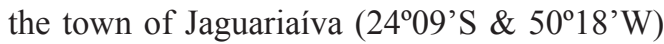
and which has a total area of 2256.62 ha (Fig. 1). The Köppen-Geiger climate classification is $\mathrm{Cfb}$ (Alvares, Stape, Sentelhas, Gonçalves, \& Sparovek, 2013). Sampling was performed only once, at the beginning of rainy season on September, 2014. The climatic conditions were temperature $22{ }^{\circ} \mathrm{C}$, humidity $66 \%$, a wind speed of $9 \mathrm{~km} / \mathrm{hand}$ light rain. Sampling was performed at three random points of the park:

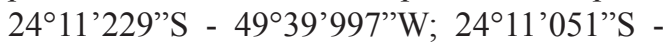
$49^{\circ} 39,992^{\prime} \mathrm{W}$ and $24^{\circ} 10^{\prime} 524^{\prime \prime} \mathrm{S}-4^{\circ} 40^{\prime} 085^{\prime \prime} \mathrm{W}$ (Fig. 1, inset) only once. Vegetation of the three points were similar, and consisted of xeromorphic vegetation, with woody trees and shrubs scattered over grassland, sometimes forming a dense bush (Linsingen, Sonehara, Uhlmann, \& Cervi, 2006). Two samples from each point were taken, being one of leaf litter and the other one of soil. Samples of leaf litter were collected and then this layer was removed. Subsequently, soil from the same point was sampled to a depth of $10 \mathrm{~cm}$ below the surface. The samples were stored in sterile plastic bags and transported at room temperature to the Environmental Microbiology Laboratory (UFSCar, Sorocaba, SP, Brazil) and kept at $4{ }^{\circ} \mathrm{C}$ for three days until the beginning of the analysis.

Physicochemical analysis: The $\mathrm{pH}$ of the soil and leaf litter samples was measured using pH-FIX 0-14 litmus paper tape (MachereyNagel, REF 92110). The soil particle size test was performed according to previously established parameters using sieved fractions (Camargo, Moniz, Jorge, \& Valadares, 2009).

Isolation and identification of filamentous fungi: Samples were weighed into three portions of $1 \mathrm{~g}$ each. Leaf litter samples were 

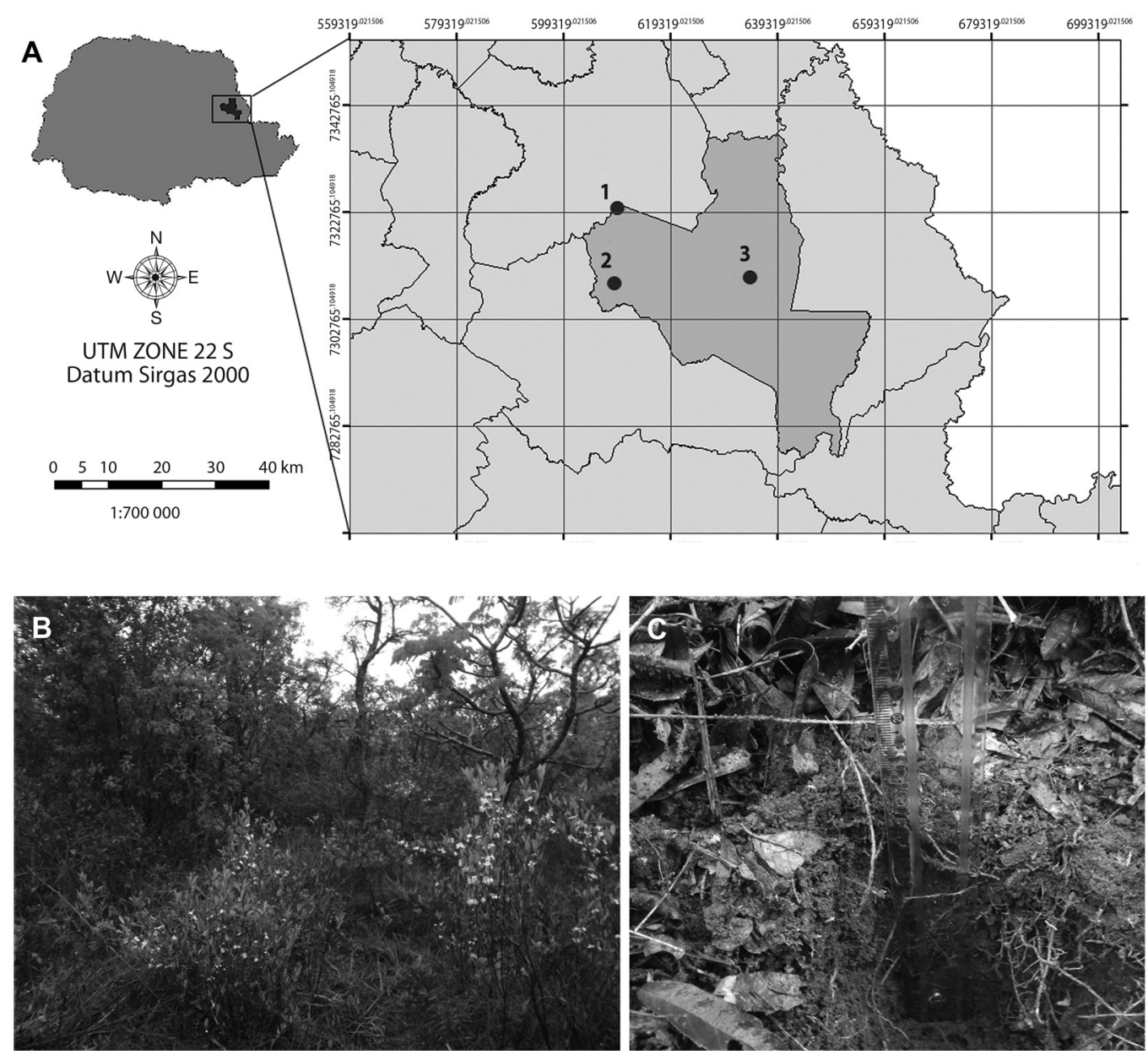

Fig. 1. A) Location of Cerrado State Park in Paraná state, Brazil. Inset shows location of sampling points inside the park (modified from www.itcg.pr.gov.br). B) Brazilian savanna vegetation in Cerrado State Park, point 1. C) Soil sampling below leaf litter cover. Plastic ruler marks sample depth. Vegetation and leaf litter cover was similar in the three sampling points.

macerated in a mortar. Soil and macerated leaf litter samples were diluted in $9 \mathrm{~mL}$ of $0.9 \%$ saline solution and serial diluted up to $10^{-5}$, without replicas. These dilutions were inoculated $(0.1 \mathrm{~mL} / \mathrm{L})$ in duplicate in medium with cellulose, adapted from Parkinson, Gray and Williams (1971), L-asparagine was substituted for peptone and $500 \mathrm{mg} / \mathrm{L}$ ampicillin (Hankin \& Anagnostakis, 1975) was added. The plates were subsequently incubated at $30{ }^{\circ} \mathrm{C}$ for five days. Selected grown colonies were transferred to potato-dextrose-agar (PDA $20 \mathrm{~g} / \mathrm{L}$ ) plates. Colony characteristics such as growth, shape and color were observed. Filamentous fungi were isolated by successive inoculations in PDA maintained at $30{ }^{\circ} \mathrm{C}$.

DNA extraction from mycelia grown in PDA for seven days were performed in accordance with Silva, Bernardi, Schaker, Menegotto, \& Valente, (2012). Partial 18S rRNA gene was amplified using the primers NL1 (5'GCATATCAATAAGCGGAGGAAAAG-3') and NL4 ( 5 '-GGTCCGTGTTTCAAGACGG-3') (Lopes, Soden, Martens, Henschke, \& Landridge, 1998). Amplification consisted of 30 cycles of denaturation at $94{ }^{\circ} \mathrm{C}$ for $45 \mathrm{~s}$, annealing at $50{ }^{\circ} \mathrm{C}$ for $1.5 \mathrm{~min}$, and extension at $72{ }^{\circ} \mathrm{C}$ for $1.5 \mathrm{~min}$. An initial 4 min denaturation 
at $94{ }^{\circ} \mathrm{C}$ and a final $7 \mathrm{~min}$ extension at 72 ${ }^{\circ} \mathrm{C}$ were performed. Amplified products were purified using Illustra GFX PCR DNA and Gel Band purification (GE Healthcare), and sequenced using a ABI PRISM 3730 DNA Analyzer (Applied Biosystems, Foster City, California, USA) with Big Dye Terminator version 3.1 Cycle Sequencing Kit (Applied Biosystems). The BLASTn tool from the National Center for Information Biotechnology was used to compare the sequences obtained with those deposited in GenBank (Benson et al., 2013). Sequences were deposited in GenBank under accession numbers KY616857 to KY616884.

Cellulase activity: The ability of the isolates to produce cellulose was tested by placing a loopful of fungi of each isolate into the center of an agar plate containing $10 \mathrm{~g} / \mathrm{L}$ carboxymethyl cellulose (CMC). The composition of the medium was $(\mathrm{g} / \mathrm{L})$ : CMC (10) and agar (10). Each plate was inoculated in duplicate and maintained for seven days at $30{ }^{\circ} \mathrm{C}$. The production of cellulose was verified by applying $10 \mathrm{~mL}$ of lugol over the colonies, and CMC-ase-positive strains were identified by the clear zones surrounding individual isolates (Kasana, Salwan, Dhar, Dutt, \& Gulati, 2008). Pleurotus sp. was used as the positive control, due to its high cellulose activity (Mandeel, AlLaith, \& Mohamed, 2005).

Lipase activity: Lipolytic activity was assessed using the medium described by Singh,

TABLE 1

Identification of fungi isolated from leaf litter and different soil types from Brazilian Savanna

\begin{tabular}{|c|c|c|c|c|c|}
\hline Sample & Taxa & \% Iden. & $\%$ cover & E value & Access number \\
\hline Soil 1 & Pleosporales & 100 & 100 & 0 & HE820842.1 \\
\hline Soil 1 & Penicillium funiculosum & 99 & 100 & 0 & HM017065.1 \\
\hline Soil 1 & Bipolaris sp. & 100 & 100 & 0 & KF553640.1 \\
\hline Soil 1 & Colletotrichum boninense & 98 & 98 & 0 & JQ754138.1 \\
\hline Soil 2 & Curvularia sp. & 100 & 100 & 0 & HG779068.1 \\
\hline Soil 2 & Trichoderma sp. & 99 & 99 & 0 & AB373724.1 \\
\hline Soil 2 & Penicillium funiculosum & 100 & 99 & 0 & HM017065.1 \\
\hline Soil 2 & Bipolaris sp. & 100 & 100 & 0 & KF553640.1 \\
\hline Soil 2 & Bjerkanderasp. & 98 & 100 & 0 & KF698751.1 \\
\hline Soil 2 & Penicillium camemberti & 100 & 99 & 0 & NG_042320.1 \\
\hline Soil 3 & Alternaria alternata & 99 & 100 & 0 & KP124545.1 \\
\hline Soil 3 & Penicilliumsp. & 97 & 100 & 0 & HМ367083.1 \\
\hline Soil 3 & Penicillium sp. & 97 & 100 & 0 & HМ367083.2 \\
\hline Soil 3 & Bjerkandera adusta & 98 & 100 & 0 & AB733334.1 \\
\hline Soil 3 & Curvularia lunata & 99 & 99 & 0 & KF590137.1 \\
\hline Leaf litter 1 & Trichoderma sp. & 99 & 99 & 0 & AB373724.1 \\
\hline Leaf litter 1 & Talaromyces sp. & 99 & 99 & 0 & AB808325.1 \\
\hline Leaf litter 1 & Penicillium verruculosum & 98 & 100 & 0 & JX863916.1 \\
\hline Leaf litter 1 & Fusarium sp. & 99 & 100 & 0 & KJ850949.1 \\
\hline Leaf litter 2 & Trametes hirsuta & 99 & 99 & 0 & AB733344.1 \\
\hline Leaf litter 2 & Hirsutella fusiforme & 100 & 99 & 0 & KJ524706.1 \\
\hline Leaf litter 2 & Trichoderma sp. & 99 & 99 & 0 & AB373724.1 \\
\hline Leaf litter 3 & Bipolaris sp. & 100 & 100 & 0 & KF553640.1 \\
\hline Leaf litter 3 & Trichoderma sp. & 99 & 99 & 0 & AB373724.1 \\
\hline Leaf litter 3 & Trichoderma sp. & 99 & 99 & 0 & AB373724.1 \\
\hline Leaf litter 3 & Bjerkandera sp. & 98 & 100 & 0 & KF698751.1 \\
\hline Leaf litter 3 & Penicillium sp. & 97 & 100 & 0 & HM367083.1 \\
\hline Leaf litter 3 & Talaromyces funiculosus & 99 & 100 & 0 & KP784313.1 \\
\hline
\end{tabular}


Gupta, Goswami, and Gupta (2006), but with fungi strains inoculated on test plates containing phenol red and tween 20. Plates were incubated at $37{ }^{\circ} \mathrm{C}$ for four days. The formation of lipolytic enzymes was verified by $\mathrm{pH}$ variation. The medium with Rhodamine B (Kouker \& Jaeger, 1987) was used to fluorimetrically detect the production of lipase. The plates were incubated at $30{ }^{\circ} \mathrm{C}$ for six days. Rhodamine $\mathrm{B}$ reacts with fatty acids and when placed under UV light, it emitted fluorescent radiation around the colonies, however, the size of the halo was too small to be measured and results were read by the emission (positive) or no emission (negative) of fluorescence.

\section{RESULTS}

A total of 28 strains of filamentous fungi were isolated from soil and leaf litter samples in CMC medium (Table 1). Most strains belonged to the Ascomycota phylum (83\%) and $17 \%$ belonged to the Basidiomycota phylum. The soil samples differed in texture and $\mathrm{pH}$ but presented a similar leaf litter cover (Fig. 1). Most isolated strains in all samples belonged to the Ascomycota phylum. The four isolated fungi from clay soil samples collected in area 1, with $\mathrm{pH} 6$, belonged to the Ascomycota phylum and two strains were identified as belonging to the order Pleosporales, one of them identified as genera Bipolaris sp., and the species Penicillium funiculosum and Colletotrichum boninense. Four Ascomycota and one Basidiomycota fungi originated from the soil samples collected in point 2 (sandy clay, $\mathrm{pH}$ 5), and were identified as the genera Curvularia sp., Trichoderma sp., Bipolaris sp., Bjerkandera sp. and the species Penicillium funiculosum and Penicillium camemberti. Soil sample 3 (sandy, pH 4) generated four Ascomycota and one Basidiomycota fungi, including the genera Penicillium sp. and the species Alternaria alternata, Bjerkandera adusta and Curvularia lunata (Table 1). The three leaf litter samples presented $\mathrm{pH} 7$, however, different fungi were isolated from each sample. Only two Basidiomycota strains were isolated from leaf litter,
Trametes sp. from leaf litter 2 and Bjerkandera sp. from leaflitter 3. Trichoderma sp. was isolated from the three samples, while Talaromyces sp. and Penicillium sp. were isolated from samples 1 and 3. Fusarium sp., Hirsutella sp. and Bipolaris sp. were isolated only once, from samples 1, 2 and 3, respectively (Table 1).

Higher cellulase activity was observed in Trichoderma sp. isolated from the soil in point 3 and Colletotrichum boninense isolated from the soil in point 1 (Table 2). All the strains were positive for at least one of the tests and eleven exhibited lipase activity in only one test, revealing that temperature can affect the lipase activity of these fungi (Bentubo \& Gompertz, 2014; Naz \& Jadhav, 2015). All the strains were tested for laccase production in mediums containing guaiacol $(4 \mathrm{mM})$, but none produced this enzyme under the applied conditions (data not shown).

\section{DISCUSSION}

Fungi of the Ascomycota phylum are usually abundant in soil samples and are generally widely distributed in soil types from arid to permafrost (Porras-Alfaro, Herrera, Natvig, Lipinski, \& Sinsabaugh, 2011; Zhang et al., 2012). In Brazilian savanna soils, they correspond to at least $49 \%$ of total fungi in riverbank forests and $61.2 \%$ in soils, with percentages increasing when this soil is converted to pasture or to soybean culture (Castro et al., 2008). Ascomycota as well as Basidiomycota strains are influenced by dry and rainy seasons (NogueiraMelo, Santos, \& Gibertoni, 2014). The abundance of Basidiomycota, however, can be higher in gallery forest soil during the dry season, when organic matter increases (Castro et al., 2016). In the sampling in the present study, carried out at the beginning of the rainy season, Ascomycota were more abundant. In Brazilian savanna soils, the precipitation regime appears to be the most important factor for determining fungal diversity (Castro et al., 2016). Other factors, however, may influence the distribution of fungi, such as aluminum level, acidity, nutrient and water availability, which can interfere with 
TABLE 2

Cellulase and lipase activitiesfrom fungi isolated from soil and leaflitter collected in Brazilian savanna

\begin{tabular}{|c|c|c|c|c|c|c|c|}
\hline Sample & Taxa & Cel. & Halo $(\mathrm{cm})$ & Mean & EI* & Lip. 1 & Lip. 2 \\
\hline S 1 & Pleosporales & + & 0.1 & 3.65 & 0.0274 & + & - \\
\hline S 1 & Penicillium funiculosum & + & 0.1 & 0.85 & 0.1177 & + & + \\
\hline S 1 & Bipolaris sp. & + & 0.35 & 4.65 & 0.0753 & + & + \\
\hline $\mathbf{S} 1$ & Colletotrichum boninense & + & 0.95 & 0.4 & 2.3750 & - & + \\
\hline S 2 & Alternaria alternata & + & 0.4 & 3.6 & 0.1111 & + & + \\
\hline S 2 & Penicillium sp. & + & 0.55 & 3.4 & 0.1618 & + & + \\
\hline S 2 & Penicillium sp. & + & 0.1 & 3.35 & 0.0299 & + & + \\
\hline S 2 & Bjerkandera adusta & + & 0.1 & 1.55 & 0.0645 & - & + \\
\hline S 2 & Curvularia luneta & + & 0.2 & 4.65 & 0.0430 & + & + \\
\hline S 2 & Bipolaris sp. & + & 0.5 & 4.65 & 0.1075 & + & - \\
\hline S 3 & Penicillium sp. & + & 0.125 & 2.95 & 0.0424 & + & + \\
\hline S 3 & Talaromyces funiculosus & + & 0.15 & 4 & 0.0375 & + & + \\
\hline S 3 & Curvularia sp. & + & 0.5 & 4.55 & 0.1099 & + & + \\
\hline S 3 & Trichoderma sp. & + & 0.5 & 0.35 & 1.4285 & + & - \\
\hline S 3 & Penicillium funiculosum & - & 0 & 0 & 0 & + & + \\
\hline LL 1 & Trichoderma sp. & + & 0.1 & 2.05 & 0.0488 & + & - \\
\hline LL 1 & Talaromyces sp. & + & 0.2 & 0.3 & 0.6667 & + & - \\
\hline LL 1 & Penicillium verruculosum & + & 0.1 & 0.5 & 0.2000 & + & - \\
\hline LL 1 & Fusarium sp. & + & 0.1 & 0.95 & 0.1053 & + & + \\
\hline LL 2 & Trichoderma sp. & + & 0.65 & 5.9 & 0.1102 & + & + \\
\hline LL 2 & Trichoderma sp. & - & 0 & 0 & 0 & + & + \\
\hline LL 2 & Bjerkandera sp. & + & 0.375 & 0.8 & 0.4688 & + & - \\
\hline LL 3 & Bipolaris sp. & + & 0.45 & 3.9 & 0.1154 & + & - \\
\hline LL 3 & Bjerkandea sp. & + & 0.25 & 0.7 & 0.3571 & + & + \\
\hline LL 3 & Penicillium camemberti & + & 0.3 & 1.55 & 0.1936 & + & + \\
\hline LL 3 & Trametes hirsuta & + & 0.1 & 0.65 & 0.1539 & + & - \\
\hline LL 3 & Hirsutella fusiforme & + & 0.2 & 2.2 & 0.0909 & + & + \\
\hline LL 3 & Trichoderma sp. & + & 0.1 & 1.15 & 0.0870 & + & - \\
\hline
\end{tabular}

$\mathrm{S}=$ Soil, LL =Leaf litter, Cel. = Cellulase activity. Data are the mean values of two independent cultures. EI* is the enzymatic index (Hankin \& Anagnostakis, 1975). Lip = Lipase. + indicates positive activity and -, negative, since halo was not observed in lipolytic activity assays. Lipase 1 was tested with phenol red while Lipase 2 was tested with Rhodamine B. The control strains for enzymatic activities were Pleurotus sp. for the cellulase test and Rhodotulura mucilaginosa for the lipase test. Bold indicates the strains with higher cellulase activity.

savanna vegetation physiology (Oliveira-Filho \& Ratter, 2002).

Respect to the fungi isolated from leaf litter samples, the Basidiomycota phylum is more common at the end of decomposition (Frankland, 1998), as the decay of lignin compounds form aromatic amines or phenols, which are generally degraded by peroxidases secreted by basidiomycetes known as "whiterot fungi” (Larrondo, Salas, Melo, Vicuña, \& Cullen, 2003; Pozdnyakova, 2012). Only two
Basidiomycota were isolated from leaf litter, one from point 2 (Trametes hirsuta) and one from point 3 (Bjerkandera sp.). The remaining 12 isolates belonged to the Ascomycota genera Fusarium, Penicillium, Trichoderma, Talaromyces, Bipolaris and Hirsutella. It is interesting to note that only four genera (Penicillium, Trichoderma, Bipolaris and Bjerkandera) occurred in the leaf litter and soil, indicating the specificity of some fungi. The cellulolytic fungi community changes over 
time during the decomposition of leaf litter (Frankland, 1998). The prevalence of Ascomycota in the samples of the present study might be explained by the fact that the leaf litter sampled was in the early stage of decomposition. It has been observed that Ascomycota has a higher relative abundance in temperate forests during the early stages while Basidiomycota increases in the latter stages (Vorísková \& Baldrian, 2013).

Ascomycota phyla, such as the Penicillium and Trichoderma genera frequently isolated in the present study, are not as important in the degradation of lignin as Basidiomycota, although they can produce cellulolytic enzymes and chitinase, being more generalist and abundant than Basidiomycota (Baldrian et al., 2011). In a survey of the cellulolytic activity of strains isolated from different materials, the majority of strains with this metabolism were isolated from soil samples (Damaso et al., 2012), confirming soil as an important source of fungi for biotechnological studies. The IE showed by the Colletotrichum boninense strain isolated in this work was similar to that presented by the control strain Pleurotus sp. $(2,2727)$, which indicates $C$. boninense as a good candidate for optimization aiming at cellulase production. It is possible that the conditions of the present study lacked an inducer for laccase production, as many fungi only express laccases in the presence of an inducer or under stressful conditions, such as low nitrogen availability or the presence of toxic substances and antibiotics (Martínez et al., 2005). Lipolytic activity was assessed under two different temperatures. Lipase secretion in endophytic fungi is higher under alkaline pHs and absent under acid pHs (Maccheroni Jr., Araújo, \& Azevedo, 2004), but the effect of temperature in lipase production has not yet been assessed. A strain identified as C. gloesporioides, isolated from Cerrado soil, has been previously characterized as an effective alkaline lipase producer (Colen, Junqueira, \& Moraes-Santos, 2006), and the strain of the same genera in the present study demonstrated lipase activity in the assay carried out at under $30^{\circ} \mathrm{C}$ and $\mathrm{pH} 7$.
The enzymatic activity of the filamentous fungi identified in this work reveals their biotechnological potential and reinforces the importance of assessing and preserving environmental resources. Fungi diversity might be reduced in soils from which vegetation has been removed (Barbosa et al., 2016) and the Brazilian savanna, from which these fungi were isolated, has been subjected to a high degree of deforestation and land-use change. This might cause the loss of these strains before their commercial potential can be assessed (Barbosa et al., 2016). With the increasing demand for renewable combustibles, the search for cellulolytic and lignocellulolytic microorganisms with high enzymatic activity is mandatory. The discovery of new strains might provide economic feasibility to second-generation biofuels, those obtained from lignocellulosic wastes, which is an important alternative to biofuels obtained from food crops.

\section{ACKNOWLEDGEMENTS}

The authors would like to thank the Environmental Institute of Parana for granting authorization (n. 35.14.), to Dirceu G. de Miranda and Ana Maria M. Miranda for their help during sampling, to Leonardo Pitombo for help with soil analysis, and Monica Almeida for help in fungi identification. M.M., A.C.V.A. and M.A.N.C. were financially supported by CAPES/Brazil research grants provided for the "Biotechnology and Environmental Monitoring" and for the "Planning and Use of Renewable Resources" research programs.

\section{RESUMEN}

Hongos celulolíticos y lipolíticos aislados a partir de muestras de suelo y de hojarasca del Cerrado (Sabana brasileña). La sabana brasileña conocida como Cerrado, es un bioma con alto grado de endemismo con el potencial de albergar muchos microorganismos de alto interés biotecnológico. Los hongos producen muchas enzimas que se aplican ampliamente en procesos industriales. El suelo del Cerrado, que suele ser ácido, es un ambiente favorable para el crecimiento de hongos capaces de degradar materiales lignocelulósicos. El objetivo del presente 
estudio fue aislar los hongos celulolíticos filamentosos nativos del Cerrado. Muestras de suelo y de hojarasca fueron recolectadas en el Parque Estatal del Cerrado, ubicado en el sur de Brasil. De 28 cepas aisladas, 25 produjeron celulasa que fue detectada con lugol. Las cepas fueron cultivadas en medio CMC (carboximetilcelulosa). Los aislados fueron identificados morfológicamente (color, forma de crecimiento) y por secuenciación de la región $18 \mathrm{~S}$ rRNA, produciendo resultados congruentes. Una cepa de Colletotrichum boninense y una cepa de Trichoderma sp., ambas aisladas de muestras de suelo, presentaron la mayor actividad celulolítica. Todas las cepas mostraron actividad lipolítica, la producción y la actividad se vieron influidos por la temperatura. El presente estudio revela nuevas cepas de hongos filamentosos conocidos con potencial de aplicación en la degradación de la biomasa, sin embargo, la optimización de las condiciones de cultivo es necesaria para lograr la viabilidad económica.

Palabras clave: celulasa; lipasa; hongos filamentosos; materiales lignocelulósicos; sabana brasileña.

\section{REFERENCES}

Alvares, C. A., Stape, J. L., Sentelhas, P. C., Gonçalves, J. L. M., \& Sparovek, G. (2013). Köppen's climate classification map for Brazil. Meteorologische Zeitschrift, 22(6), 711-728.

Balat, M. (2011). Production of bioethanol from lignocellulosic materials via the biochemical pathway: A review. Energy Conversion Management, 52, 858-875.

Baldrian P., Voříšková J., Dobiášová P., Merhautová V., Lisá, L., \& Valášková, V. (2011). Production of extracellular enzymes and degradation of biopolymers by saprotrophic microfungi from the upper layers of forest soil. Plant Soil, 338, 111-125.

Barbosa, R. N., Bezerra, J. D. P., Costa, P. M. O., LimaJúnior, N. C., Galvão, I. R. G. A. S., Santos-Júnior, A. A., Fernandes, M. J., Souza-Motta, C. M., \& Oliveira, N. T. (2016). Aspergillus and Penicillium (Eurotiales: Trichocomaceae) in soils of the Brazilian tropical dry forest: diversity in an area of environmental preservation. Revista de Biología Tropical, 64(1), 45-53.

Benson, D. A., Cavanaugh, M., Clark, K., Karsch-Mizrachi, I., Lipman, D. J., Ostell, J., \& Sayers, E. W. (2013). GenBank. Nucleic Acids Research, 41(Database issue), D36-42.

Bentubo, H. D. L., \& Gompertz, O. F. (2014). Effects of temperature and incubation time on the in vitro expression of proteases, phospholipases, lipases and DNases by different species of Trichosporon. Springer Plus, 3, 377.

Bhat, M. K. (2000). Cellulases and related enzymes in biotechnology. Biotechnology Advances, 18(5), 355-383.
Blackwell, M. (2011). The Fungi: 1, 2, 3 ... 5.1 million species? American Journal of Botany, 98, 426-438.

Camargo, O. A., Moniz, A. C., Jorge, J. A., \& Valadares, J. M. A. S. (2009). Métodos de análise química e física de solos do Instituto Agronômico de Campinas. Boletim técnico, 106, 46-49.

Castro, A. P., Quirino, B. F., Papas, G. Jr., Kurokawa, A. S., Leonardecz, E., \& Krüger, R. H. (2008). Diversity of soil fungal communities of Cerrado and its closely surrounding agriculture fields. Archives of Microbiology, 190, 129-139.

Castro, A. P., Silva, M. R. S. S., Quirino, B. F., Bustamante, M. M. C., \& Krüger, R. H. (2016). Microbial Diversity in Cerrado Biome (Neotropical Savanna) Soils. PLoSONE, 11(2), e0148785.

Colen, G., Junqueira, R. G., \& Moraes-Santos, T. (2006). Isolation and screening of alkaline lipase-producing fungi from Brazilian savanna soil. World Journal Microbiology Biotechnology, 22, 881-885.

Damaso, M. C. T., Terzi, S. C., Farias, A. X., Oliveira, A. C. P., Fraga, M. E., \& Couri, S. (2012). Selection of Cellulolytic Fungi Isolated from Diverse Substrates. Brazilian Archives of Biology and Technology, 55, 513-520.

Frankland, J. C. (1998). Fungal succession - unravelling the unpredictable. Mycology Research, 102, 1-15.

Hankin, L., \& Anagnostakis, S. L. (1975). The use of solid media for the detection of enzyme production by fungi. Mycologia, 6, 7597-607.

Hasan, F., Shah, A. A., \& Hameed, A. (2006) Industrial applications of microbial lipases. Enzyme and Microbial Technology, 39, 235-251.

Hodásová, L., Jablonský, M., Škulcová, A., \& Ház, A. (2015) Lignin, potential products and their market value. Wood Research, 60(6), 73-986.

Karlsson, S., Holmbom, B., Spetz, P., Mustranta, A., \& Buchert, J. (2001). Reactivity of Trametes laccases with fatty and resin acids. Applied Microbiology and Biotechnology, 55, 317-320.

Kasana, R. C., Salwan, R., Dhar, H., Dutt, S., \& Gulati, A. (2008). A rapid and easy method for the detection of microbial cellulases on agar plates using gram's iodine. Current Microbiology, 57, 503-507.

Kathiresan, K. (2001) Polythene and Plastics-degrading microbes from the mangrove soil. Revista de Biología Tropical, 51(3), 629- 634

Klemm D., Heublein B., Fink H., \& Bohn A. (2005). Cellulose: Fascinating Biopolymer and Sustainable Raw Material. Angewante Chemie International Edition English, 44(22), 358-93.

Korkama-Rajala, T., Mueller, M. M., \& Pennanen, T. (2008). Decomposition and fungi of needle litter from 
slow and fast-growing Norway spruce (Piceaabies) clones. Microbial Ecology, 56, 76-89.

Kouker, G., \& Jaeger, K. E. (1987). Specific and sensitive plate assay for bacterial lipases. Applied Environmental Microbiology, 53, 211-213.

Lange, L., Bech, L., Busk, P. K., Grell, M. N., Huang, Y., Lange, M., Linde, T., ... Tong, X. (2012). The importance of fungi and of mycology for a global development of the bioeconomy. IMA Fungus, 3, 87-92.

Larrondo, L. F., Salas, L., Melo, F., Vicuña, R., \& Cullen, D. (2003) A Novel Extracellular Multicopper Oxidase from Phanerochaete chrysosporium with Ferroxidase Activity. Applied Environmental Microbiology, 69, 6257-6263.

Linsingen, L., Sonehara, J. S., Uhlmann, A., \& Cervi, A. (2006) Composição florística do Parque Estadual do Cerrado de Jaguariaíva, Paraná, Brasil. Acta Biológica Paranaense, 35,197-232.

Lopes, M. B., Soden, A., Martens, A., Henschke, P. A., \& Landridge, P. (1998). Differentiation and species identification of yeasts using PCR. International Journal of Systematic Bacteriology, 48, 79-286.

Maccheroni Jr., W., Araújo, W. L, \& Azevedo, J. L. (2004) Ambient pH-regulated enzyme secretion endophytic and pathogenic isolate of the fungal genus Colletotrichum. Scentia Agricola, 61, 298-302.

Maia, L. C., Carvalho Jr, A. A., Cavalcanti, L. H., Gugliotta, A. M., Drechsler-Santos, E. R., Santiago, A. L. M. A., Cáceres, M. E., ... da Silva, V. F. (2015). Diversity of Brazilian Fungi. Rodriguésia, 66, 1033-1045.

Mandeel, Q. A., Al-Laith, A. A., \& Mohamed, S. A. (2005) Cultivation of oyster muhsrooms (Pleurotus sp.) on various lignocellulosic wastes. World Journal Microbiology Biotechnology, 21, 601-607.

Martínez A. T., Speranza M., Ruiz-Dueñas F. J., Ferreira P., Camarero S., Guillén F., Martínez, M. J., Gutiérrez, A., \& del Río, J. C. (2005). Biodegradation of lignocellulosics: microbial, chemical and enzymatic aspects of the fungal attack of lignin. International Microbiology, 8, 195-204.

Naz, S., \& Jadhav, S. K. (2015). Studies of the estimation of lipase production capability of some fungal species and their application in oil spillage degradation. International Journal of Science and Research (IJSR), 4, 2154-2159.

Nogueira-Melo, G. S., Santos, P. J. P., \& Gibertoni, T. B. (2014). The community structure of macroscopic basidiomycetes (Fungi) in Brazilian mangroves influenced by temporal and spatial variations. Revista de Biología Tropical, 62(4), 1587-1595.

Oliveira, J. M. P. F., \& Graaff, L. H. (2011) Proteomics of industrial fungi: trends and insights for biotechnology. Applied Microbiology Biotechnology, 89, 225-237.
Oliveira-Filho, A. T., \& Ratter, J. A. (2002). Vegetation physiognomies and woody flora of the Cerrado biome. In P. S. Oliveira \& R. J. Marquis (Eds.), The Cerrados of Brazil (pp. 91-120). New York: Columbia University Press.

Parkinson D., Gray T. R. G., \& Williams, S. T. (1971). Methods for studying the ecology of soil microorganisms. Oxford: Blackwell Scientific Publications.

Porras-Alfaro, A., Herrera, J., Natvig, D. O., Lipinski, K., \& Sinsabaugh, R. L. (2011). Diversity and distribution of soil fungal communities in a semiarid grassland. Mycologia, 103(1), 10-21.

Pozdnyakova, N. N. (2012). Involvement of the Ligninolytic System of White-Rot and Litter-Decomposing Fungi in the Degradation of Polycyclic Aromatic Hydrocarbons. Biotechnology Research International, 2012, 243.

Silva, G. A., Bernardi, T. L., Schaker, P. D. C., Menegotto, M., \& Valente, P. (2012) Rapid Yeast DNA Extraction by Boiling and Freeze-Thawing without using chemical reagents and DNA Purification. Brazilian Archives of Biology and Technology, 55(2), 319-327.

Singh, R., Gupta, N., Goswami, V. K., \& Gupta, R. (2006). A simple activity staining protocol for lipases and esterases. Applied Microbiology and Biotechnology, 70, 679-682.

Sticklen, M. B. (2008). Plant genetic engineering for biofuel production: towards affordable cellulosic ethanol. Nature Genetics, 9, 433-443.

Trancoso, R., Sano, E. E., \& Meneses, P. R. (2015). The spectral changes of deforestation in the Brazilian tropical savanna. Environmental Monitoring and Assessment, 187, 41-45.

Valencia, E. Y., \& Chambergo, F. S. (2013). Mini-review: Brazilian fungi diversity for biomass degradation. Fungal Genetics Biology, 60, 9-18.

Vieira, M. L. A., Johann, S., Hughes, F. M., Rosa, C. A., \& Rosa, L. H. (2014). The diversity and antimicrobial activity of endophytic fungi associated with medicinal plant Baccharistrimera (Asteraceae) from the Brazilian savanna. Canadian Journal of Microbiology, $60,847-856$.

Viswanath, B., Rajesh, B., Janardhan, A., Kumar, A. P., \& Narasimha, G. (2014). Fungal laccases and their applications in bioremediation. Enzyme Research, 2014, id63242. doi:10.1155/2014/163242

Vorísková, J., \& Baldrian, P. (2013). Fungal community on decomposing leaf litter undergoes rapid successional changes. ISME Journal, 7, 477-486.

Zhang, X. F., Zhao, L., Xu S. J. Jr., Liu, Y. Z., Liu, H. Y., \& Cheng G. D. (2012) Soil moisture effect on bacterial and fungal community in Beilu River (Tibetan Plateau) permafrost soils with different vegetation types. Journal of Applied Microbiology, 114, 1054-65. 